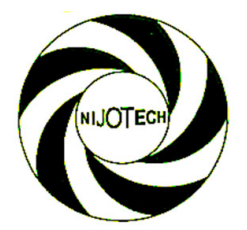

Nigerian Journal of Technology (NIJOTECH)

Vol. 35, No. 1, January 2016, pp. 129 - 136

Copyright@ Faculty of Engineering, University of Nigeria, Nsukka,

Print ISSN: 0331-8443, Electronic ISSN: 2467-8821

www.nijotech.com

http://dx.doi.org/10.4314/njt.v35i1.20

\title{
INVESTIGATION OF FOULING EFFECT ON OVERALL PERFORMANCE OF SHELL AND TUBE HEAT EXCHANGER IN A UREA FERTILIZER PRODUCTION COMPANY IN NIGERIA
}

\author{
M. A. Sulaiman ${ }^{1, *}$, S. I. Kuye ${ }^{2}$ and S. A. Owolabi ${ }^{3}$ \\ 1, 3 MECHANICAL ENGINEERING DEPARTMENT, Olabisi ONABANJo UNIVERSITY, OGUN STATE. NIGERIA

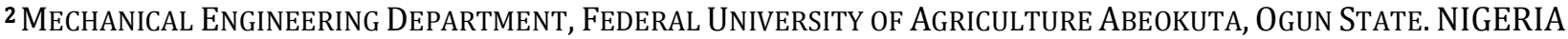 \\ E-mail addresses: ${ }^{1}$ sulaiman.adedoyin@gmail.com, ${ }^{2}$ ibiyemikuye@yahoo.com, ${ }^{3}$ owolasmart@yahoo.com
}

\begin{abstract}
Fouling is one of the major problems confronting heat exchangers in most industries. Shell and tube heat exchangers are perhaps the most common types of heat exchangers in industrial applications due to their flexibility and versatility. This study investigated the effect of fouling on the performance of the shell and tube heat exchanger unit of a $\mathrm{CO}_{2}$ fertilizer production company in Nigeria. Two different heat exchanger units (cold gas pre-heater and $\mathrm{CO}_{2}$ water cooler in scrubbing process) were considered for the analysis of this study. Data were obtained from operational log book, periodic maintenance data sheet and vendor' design data sheet. The data were analyzed using various energy equations encoded in MATLAB to determine the overall heat transfer coefficients, heat duties, capacity ratios and effectiveness. The results obtained from the analysis showed that on average, the deviation of overall heat transfer coefficient, heat duty, and effectiveness from design values were $24.10 \%, 26.27 \%$, and $17.17 \%$ respectively. Fouling factor was $31.58 \%$ more than the design value in a period of 47 days of operation. Fouling adversely affects the performance parameters of the heat exchangers.
\end{abstract}

Keywords: Fouling, Heat exchanger, heat duty, Shell and tube and Performance

\section{INTRODUCTION}

In various systems and processes that make use of heat energy for one purpose or the other, there is a need for the transfer of heat. The devices that help in transferring heat from one process fluid to another are called heat exchangers. They facilitate the exchange of heat between two fluids that are at different temperatures while keeping them from mixing with each other [1]. Heat exchangers are commonly used in practice in a wide range of applications. The energy transferred in a heat exchanger may be in form of latent heat, as in boilers and condensers or sensible heat as in heaters or coolers. The shell and tube heat exchanger is a type of heat exchanger which consists of a series of tubes containing the primary fluid that must be either heated or cooled with the secondary fluid being circulated over the tubes. These types of heat exchangers are perhaps the most common in industrial applications. Improper design and irregular maintenance of heat exchangers may result in the damage or degradation of the components and performance of the units [2].

There are many problems that confront the heat exchangers but the major cause of reduction in heat exchanger performance is the effect of fouling [3]. Fouling is generally defined as the accumulation and formation of unwanted materials on the surfaces of process equipment, which can seriously reduce the capacity of the surface to transfer heat under the temperature difference conditions for which it was designed [4]. Whatever the cause or exact nature of the deposit, additional resistances to heat transfer is introduced and the operational capability of the heat exchanger is correspondingly reduced. In many cases, the deposit is heavy enough to significantly interfere with the fluid flow and increase the pressure drop required to maintain the flow rate through the exchanger. There are several different basic mechanisms by which fouling deposits may be created 
and each of them generally depends upon several variables. In addition, two or more fouling mechanisms can occur together in a given service [5]. Generally, process parameters such as fluid flow velocity, surface temperature, surface roughness, fluid properties and plate geometry affect the formation of deposits.

Fouling effect has always been a recognized phenomenon, but poorly understood. Lack of a regular, effective analysis and evaluation of fouling effect on performance of industrial equipment has contributed immensely to the potency of fouling effect in heat exchangers. It is therefore with a view to avoiding down time, reduction in overall heat transfer, increase in capital investment, and loss of production, that there is a need to carry out theoretical analysis and periodic investigation of fouling effect on overall performance of shell and tube heat exchangers being used in industrial applications.

Several researchers have carried out various studies in recent years on performance evaluation methods of heat exchangers. Studies have been developed and used to evaluate and improve their performance. The study on influence of fouling on heat exchanger effectiveness in a polyethylene plant was carried out by Lebele-Alawa and Okpara [2]. This study evaluated the effects of fouling on three heat exchanger units (Pump around cooler, First stage condenser and pre heater) in a polyethylene plant. Data for those units were obtained through steady state monitoring and direct measurement from the plant. The result of the analyzed data showed that the overall heat transfer coefficient for the pump around cooler was 51.60\% less than the design value. The heat duty and the overall heat transfer coefficient for the first stage condenser were $86.39 \%$ and $80.71 \%$ less than the design value respectively. The results also showed an increase of $57.73 \%$ of the fouling factor over the design value which also affected the effectiveness and capacity ratio of the heat exchangers. This was traceable to increased fouling that has affected the effectiveness, capacity ratio and temperature range of the hot and cold fluid. In the pre heater unit the heat duty was found to be $80.14 \%$ of the design value, while the overall heat transfer coefficient was $15 \%$ more than the design value. This was due to variation in temperature difference between plant data and design value in the hot fluid side of the exchanger which has also affected the pressure drop. Kukulka [6] evaluated the effect of surface coating on fouling on a compact plate heat exchangers and transient observation of heat transfer surface appearance, where new and cleaned coated heat exchangers that have been exposed to untreated lake water for various time periods were considered. Results indicated that the thermal performance of the unit decreased with time, resulting in undersized heat exchangers. Bell et al. [7] investigated the effects of particulate fouling air side pressure on heat exchanger for a hybrid dry cooler. The result of the investigation showed that the effect of fouling in the case was small. Ishiyama et al. [8] understudied the effect of fouling on heat transfer, pressure drop and throughput in refinery preheats. The study was able to explore the effects using engineering analysis and fouling rate laws based on the "threshold fouling" concept to highlight the importance of foulant thermal conductivity in the refinery preheat. Genic et al. [9] investigated the effects of fouling in plate heat exchanger using four district heating substations. Result of this analysis showed that the operation of the heat duty of the exchanger reduced due to fouling. Kho [10] in their work, investigated the effect of providing excess surface area on fouling, found out that the excess area provided for the heat transfer reduced the fouling rate of the heat exchanger but increased the cost due to materials oversizing. The experiment was done on plate heat exchanger by adding more plates to modify its geometry. The result further showed that minimum fouling occurred when $20 \%$ excess surface area was provided by a two-pass arrangement of the original plates. The poorest performance was obtained when the excess surface was simply added as parallel plates. As it can be seen, fouling in heat exchangers adversely affects the transfer of heat in the process plant is a very serious issue. Therefore this work, intends to evaluate the effect of fouling on heat exchangers in a Nigeria fertilizer company. The outcomes of this study will be useful for determining the appropriate time schedules for the maintenance of the heat exchangers.

\section{MATERIALS AND METHODS}

This study considered the effect of fouling on overall performance of shell and tube heat exchangers. The pertinent parameters considered include fouling factor, overall heat transfer coefficient, heat duty, temperature ranges of hot and cold fluids, pressure drop, capacity ratio and effectiveness.

In this study, data was collected from a carbon dioxide scrubbing process unit in a urea fertilizer production company in Nigeria. One year data of the main heat exchanger units was collected for the analysis. The 
main heat exchanger unit considered was $\mathrm{CO}_{2}$ water cooler in scrubbing process. Data from operational log book from January 2014 to January 2015 were used. Data obtained from equipment during periodic maintenance and vendor's design data sheet were also considered. The parameters considered during the data collection were inlet and outlet temperature and pressure of the process fluid, cooling water and the flow rate. In the course of analysis and treatment of data, mean values of daily parameters were calculated using statistical method. After this, the average values for seven (7) days were analyzed and the results were determined by inputting the average data calculated into the various energy equations encoded with MATLAB computer program. In this work, seven days average data were analysed due to the fact that the heat exchanger maintenance is carried out between 47-50 days of operation. The parameters such as fouling factor, overall heat transfer coefficient, heat duty, temperature ranges of hot and cold fluids, pressure drop, capacity ratio and effectiveness were computed. Figure 1 shows the block diagram of a typical shell and tube heat exchanger.

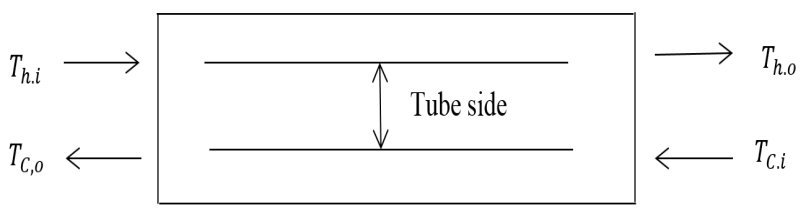

Fig.1 Block diagram of a shell and tube heat exchanger

\subsection{Investigated Parameters}

\subsubsection{Fouling Factor $\left(R_{f}\right)$}

Fouling factor measures the thermal resistance introduced in heat exchanger by fouling. It is the reciprocal of the heat transfer coefficient of the dirt formed in the heat exchange process. The higher the factor, the lower the overall heat transfer coefficient [11]. It is given by

$$
R_{f}=\frac{1}{U_{\text {cal }}}-\frac{1}{U_{\text {clean }}}
$$

where,

$U_{c a l}$ is the Overall heat transfer coefficient calculated from data and $U_{\text {clean }}$ is the Design Overall heat.

Overall Heat Transfer Coefficient (U)

The overall heat transfer coefficient is the ratio of heat flux per unit difference in approach across heat exchanger equipment considering the individual coefficient and heat exchanger metal surface conductivity. The magnitude indicates the ability of heat transfer for a given surface. The higher the coefficient, the lower the heat transfer surface requirement [1].

$$
U=\frac{Q}{A_{s} \Delta T_{i m}}
$$

where,

$\Delta T_{l m}$ is the Logarithmic mean temperature difference, $A_{s}$ is the Heat transfer surface, $Q$ is the Rate of heat transfer

$$
\begin{aligned}
& \Delta T_{i m}=\frac{\Delta T_{1}-\Delta T_{2}}{\operatorname{In}\left(\frac{\Delta T_{1}}{\Delta T_{2}}\right)} \\
& \Delta T_{1}=T_{h, 1}-\Delta T_{c, o} \\
& \Delta T_{2}=T_{h, o}-\Delta T_{c, i}
\end{aligned}
$$

\subsubsection{Heat Duty $\left(Q_{h}\right)$}

This is the capacity of the heat exchanger equipment expressed in terms of heat transfer per unit time. It means the exchanger is capable of performing at this capacity in the given system. Heat duty can be defined as the heat gained by cold fluid which is equal to the heat loss of the hot fluid [5] and it is given by

$$
Q_{h}=m_{h} C_{p h}\left(T_{h, i}-T_{h, o}\right)
$$

where,

$Q_{h}$ is the heat duty, $C_{p h}$ is the heat capacity of hot fluid, $\dot{\mathrm{m}}_{\boldsymbol{h}}$ is the mass flow rate of hot the fluid and $t_{h i}, t_{h o}$ are temperatures at inlet and outlet respectively.

\subsubsection{Capacity Ratio $R$}

This is the ratio of the temperature range of the hot fluid to that of the cold fluid and is expressed as [2]

$$
R=\frac{T_{h, i}-T_{h, o}}{T_{c, o}-T_{c, i}}
$$

\subsubsection{Effectiveness $\varepsilon$}

This is the ratio of cold fluid temperature range to that of the inlet temperature difference of the hot and cold fluid. It can also be defined as the ratio of the actual heat transfer in heat exchanger to the maximum heat transfer [4].

$$
\varepsilon=\frac{Q_{a c t}}{Q_{\max }}
$$

where,

$$
\begin{aligned}
& Q_{a c t}=\dot{m}_{c} C_{p c}\left(T_{c, o}-T_{c, i}\right) \\
& Q_{\text {max }}=C_{\text {mim }}\left(T_{h, i}-T_{c, i}\right)
\end{aligned}
$$

\section{RESULTS AND DISCUSSIONS}

The results of the analysis of data obtained from the shell and tube heat exchanger used in the scrubbing processes in the fertilizer plant are presented in Tables 1-7 below. 
Investigation of Fouling Effect on Overall Performance of Shell And Tube Heat Exchanger,...M. A. Sulaiman et al

Table 1 Result of $\mathrm{CO}_{2}$ Water Cooler on 7th Day of Operation

\begin{tabular}{lccc} 
Parameters & Design data & Average data Cal & Value \pm deviation (\%) \\
\hline 1. Heat transfer coefficient $\left(W / m^{2 o} C\right)$ & 1096.22 & 1053.14 & 3.93 \\
2. Fouling factor $\left(m^{2 o} C / W\right)$ & 0.000912 & 0.00095 & 4.09 \\
3. Heat duty $(\mathrm{kW})$ & 689.15 & 680.94 & 1.19 \\
4. Effectiveness (NIL) & 0.8 & 0.75 & 6.07 \\
5. Capacity ratio (NIL) & 0.0209 & 0.021 & 0.96 \\
6. Hot fluid temp. range $\left({ }^{\circ} \mathrm{C}\right)$ & 62 & 61.44 & 0.9 \\
7. Cold fluid temp range $\left({ }^{\circ} \mathrm{C}\right)$ & 10 & 10 & 0 \\
8. LMTD $\left({ }^{\circ} \mathrm{C}\right)$ & 19.7 & 20.57 & 4.39 \\
9. Flow rate $(\mathrm{kg} / \mathrm{s})$ & 250 & 249.97 & 0.012 \\
10. Pressure drop on shell side $(\mathrm{bar})$ & 1.4 & 1.38 & 1.43 \\
11. Pressure drop on tube side $(\mathrm{bar})$ & 3.1 & 3.07 & 0.97 \\
12. Mass flow rate of hot fluid $(\mathrm{kg} / \mathrm{s})$ & 13.17 & 13.14 & 0.23 \\
13. Mass flow rate of cold fluid $(\mathrm{kg} / \mathrm{s})$ & 126.16 & 124.91 & 4.16 \\
\hline
\end{tabular}

Table 2 Result of $\mathrm{CO}_{2}$ Water Cooler on the 14th Day of Operation

\begin{tabular}{lrrc}
\hline Parameters & Design data & Average data Cal & Value \pm deviation (\%) \\
\hline 1. Heat transfer coefficient $\left(W / m^{2 o} C\right)$ & 1096.22 & 1035.62 & 5.53 \\
2. Fouling factor $\left(m^{2 o} C / W\right)$ & 0.000912 & 0.000966 & 5.92 \\
3. Heat duty (kW) & 689.15 & 676.87 & 1.78 \\
4. Effectiveness (NIL) & 0.8 & 0.75 & 6.25 \\
5. Capacity ratio (NIL) & 0.0209 & 0.022 & 6.16 \\
6. Hot fluid temp. range $\left({ }^{\circ} \mathrm{C}\right)$ & 62 & 61.22 & 1.26 \\
7. Cold fluid temp range $\left({ }^{\circ} \mathrm{C}\right)$ & 10 & 9.98 & 0.2 \\
8. LMTD $\left({ }^{\circ} \mathrm{C}\right)$ & 19.7 & 20.82 & 5.68 \\
9. Flow rate $(\mathrm{kg} / \mathrm{s})$ & 250 & 249.78 & 0.098 \\
10. Pressure drop on shell side (bar) & 1.4 & 1.35 & 3.57 \\
11. Pressure drop on tube side (bar) & 3.1 & 3.01 & 2.9 \\
12. Mass flow rate of hot fluid $(\mathrm{kg} / \mathrm{s})$ & 13.17 & 13.1 & 0.53 \\
13. Mass flow rate of cold fluid $(\mathrm{kg} / \mathrm{s})$ & 126.16 & 118.65 & 5.95 \\
\hline
\end{tabular}

Table 3 Result of $\mathrm{CO}_{2}$ Water Cooler on the 21st Day of Operation

\begin{tabular}{lrrc}
\hline Parameters & Design data & Average data Cal & Value \pm deviation (\%) \\
\hline 1. Heat transfer coefficient $\left(W / m^{2 o} C\right)$ & 1096.22 & 1003.14 & 8.48 \\
2. Fouling factor $\left(m^{20} C / W\right)$ & 0.000912 & 0.000997 & 9.32 \\
3. Heat duty $(\mathrm{kW})$ & 689.15 & 670.4 & 2.72 \\
4. Effectiveness (NIL) & 0.8 & 0.73 & 9.07 \\
5. Capacity ratio $(\mathrm{NIL})$ & 0.0209 & 0.023 & 10.73 \\
6. Hot fluid temp. range $\left({ }^{\circ} \mathrm{C}\right)$ & 62 & 60.82 & 1.9 \\
7. Cold fluid temp range $\left({ }^{\circ} \mathrm{C}\right)$ & 10 & 9.68 & 3.2 \\
8. LMTD $\left({ }^{\circ} \mathrm{C}\right)$ & 19.7 & 21.43 & 8.79 \\
9. Flow rate $(\mathrm{kg} / \mathrm{s})$ & 250 & 249.41 & 0.24 \\
10. Pressure drop on shell side $(\mathrm{bar})$ & 1.4 & 1.31 & 6.43 \\
11. Pressure drop on tube side $(\mathrm{bar})$ & 3.1 & 2.89 & 6.77 \\
12. Mass flow rate of hot fluid $(\mathrm{kg} / \mathrm{s})$ & 13.17 & 13.06 & 0.84 \\
13. Mass flow rate of cold fluid $(\mathrm{kg} / \mathrm{s})$ & 126.16 & 113.4 & 10.11 \\
\hline
\end{tabular}

Table 4: Result of $\mathrm{CO}_{2}$ Water Cooler on the 28th Day of Operation 
Investigation of Fouling Effect on Overall Performance of Shell And Tube Heat Exchanger,...M. A. Sulaiman et al

\begin{tabular}{lrrc}
\hline Parameters & Design data & Average data Cal & Value \pm deviation (\%) \\
\hline 1. Heat transfer coefficient $\left(W / m^{2 o} C\right)$ & 1096.22 & 935.98 & 14.64 \\
2. Fouling factor $\left(m^{20} C / W\right)$ & 0.000912 & 0.001068 & 17.11 \\
3. Heat duty $(\mathrm{kW})$ & 689.15 & 656.43 & 4.75 \\
4. Effectiveness (NIL) & 0.8 & 0.7 & 13.39 \\
5. Capacity ratio (NIL) & 0.0209 & 0.024 & 16.47 \\
6. Hot fluid temp. range $\left({ }^{\circ} \mathrm{C}\right)$ & 62 & 59.92 & 3.35 \\
7. Cold fluid temp range $\left({ }^{\circ} \mathrm{C}\right)$ & 10 & 9.22 & 7.8 \\
8. LMTD $\left({ }^{\circ} \mathrm{C}\right)$ & 19.7 & 22.69 & 15.18 \\
9. Flow rate $(\mathrm{kg} / \mathrm{s})$ & 250 & 248.94 & 0.42 \\
10. Pressure drop on shell side (bar) & 1.4 & 1.26 & 10 \\
11. Pressure drop on tube side $(\mathrm{bar})$ & 3.1 & 2.78 & 10.32 \\
12. Mass flow rate of hot fluid $(\mathrm{kg} / \mathrm{s})$ & 13.17 & 12.98 & 1.44 \\
13. Mass flow rate of cold fluid $(\mathrm{kg} / \mathrm{s})$ & 126.16 & 107.15 & 15.07 \\
\hline
\end{tabular}

Table 5 Result of $\mathrm{CO}_{2}$ Water Cooler on the $35^{\text {th }}$ Day of operation

\begin{tabular}{lccc}
\hline Parameters & Design data & Average data Cal & Value \pm deviation (\%) \\
\hline 1. Heat transfer coefficient $\left(W / \mathrm{m}^{2 o} \mathrm{C}\right)$ & $1,096.22$ & 836.62 & 23.68 \\
2. Fouling factor $\left(\mathrm{m}^{20} \mathrm{C} / \mathrm{W}\right)$ & 0.000912 & 0.001195 & 31.03 \\
3. Heat duty $(\mathrm{kW})$ & 689.15 & 629.41 & 8.65 \\
4. Effectiveness (NIL) & 0.80 & 0.66 & 17.52 \\
5. Capacity ratio (NIL) & 0.0209 & 0.0259 & 23.96 \\
6. Hot fluid temp. range $\left({ }^{o} \mathrm{C}\right)$ & 62 & 57.9 & 6.61 \\
7. Cold fluid temp range $\left({ }^{\circ} \mathrm{C}\right)$ & 10 & 8.78 & 12.20 \\
8. LMTD $\left({ }^{\circ} \mathrm{C}\right)$ & 19.70 & 25.12 & 27.54 \\
9. Flow rate $\left({ }^{\circ} \mathrm{C}\right)$ & 250 & 248.42 & 0.63 \\
10. Pressure drop on shell side $(\mathrm{bar})$ & 1.40 & 1.21 & 13.57 \\
11. Pressure drop on tube side $(\mathrm{bar})$ & 3.1 & 2.62 & 15.48 \\
12. Mass flow rate of hot fluid $(\mathrm{kg} / \mathrm{s})$ & 13.17 & 12.88 & 2.20 \\
13. Mass flow rate of cold fluid $(\mathrm{kg} / \mathrm{s})$ & 126.16 & 99.9 & 20.81 \\
\hline
\end{tabular}

Table 6 Result of $\mathrm{CO}_{2}$ Water Cooler on the $42^{\text {nd }}$ Day of operation

\begin{tabular}{lccc}
\hline Parameters & Design data & Average data Cal & Value \pm deviation (\%) \\
\hline 1. Heat transfer coefficient $\left(\mathrm{W} / \mathrm{m}^{2 o} \mathrm{C}\right)$ & $1,096.22$ & 649.57 & 40.74 \\
2. Fouling factor $\left(\mathrm{m}^{20} \mathrm{C} / \mathrm{W}\right)$ & 0.000912 & 0.001539 & 68.75 \\
3. Heat duty $(\mathrm{kW})$ & 689.15 & 566.31 & 17.82 \\
4. Effectiveness (NIL) & 0.80 & 0.55 & 31.24 \\
5. Capacity ratio (NIL) & 0.0209 & 0.0275 & 31.52 \\
6. Hot fluid temp. range $\left({ }^{\circ} \mathrm{C}\right)$ & 62 & 52.38 & 15.52 \\
7. Cold fluid temp range $\left({ }^{\circ} \mathrm{C}\right)$ & 10 & 7.38 & 26.80 \\
8. LMTD $\left({ }^{\circ} \mathrm{C}\right)$ & 19.70 & 30.85 & 56.61 \\
9. Flow rate $\left({ }^{\circ} \mathrm{C}\right)$ & 250 & 247.84 & 0.86 \\
10. Pressure drop on shell side $(\mathrm{bar})$ & 1.40 & 1.15 & 1.7 .86 \\
11. Pressure drop on tube side $(\mathrm{bar})$ & 3.1 & 2.54 & 18.06 \\
12. Mass flow rate of hot fluid $(\mathrm{kg} / \mathrm{s})$ & 13.17 & 12.81 & 2.73 \\
13. Mass flow rate of cold fluid $(\mathrm{kg} / \mathrm{s})$ & 126.16 & 93.65 & 25.77 \\
\hline
\end{tabular}




\begin{tabular}{lccc}
\hline Parameters & Design data & Average data Cal & Value \pm deviation (\%) \\
\hline 1. Heat transfer coefficient $\left(W / \mathrm{m}^{2 o} \mathrm{C}\right)$ & $1,096.22$ & 559.70 & 48.94 \\
2. Fouling factor $\left(\mathrm{m}^{20} \mathrm{C} / \mathrm{W}\right)$ & 0.000912 & 0.001787 & 95.94 \\
3. Heat duty $(\mathrm{kW})$ & 689.15 & 498.11 & 27.72 \\
4. Effectiveness (NIL) & 0.80 & 0.47 & 41.76 \\
5. Capacity ratio (NIL) & 0.0209 & 0.03 & 37.45 \\
6. Hot fluid temp. range $\left({ }^{\circ} \mathrm{C}\right)$ & 62 & 47.32 & 23.68 \\
7. Cold fluid temp range $\left({ }^{\circ} \mathrm{C}\right)$ & 10 & 6.2 & 38.00 \\
8. LMTD $\left({ }^{\circ} \mathrm{C}\right)$ & 19.70 & 36.20 & 83.77 \\
9. Flow rate $\left({ }^{\circ} \mathrm{C}\right)$ & 250 & 247.38 & 1.05 \\
10. Pressure drop on shell side $(\mathrm{bar})$ & 1.40 & 1.08 & 22.86 \\
11. Pressure drop on tube side $(\mathrm{bar})$ & 3.1 & 2.38 & 23.23 \\
12. Mass flow rate of hot fluid $(\mathrm{kg} / \mathrm{s})$ & 13.17 & 12.78 & 2.96 \\
13. Mass flow rate of cold fluid $(\mathrm{kg} / \mathrm{s})$ & 126.16 & 89.4 & 29.14 \\
\hline
\end{tabular}

From this table, the results show that there was slight variation in the values of performance parameters of the $\mathrm{CO}_{2}$ water cooler from the design data. The overall heat transfer coefficient and the heat duty were $3.93 \%$ and $1.19 \%$ respectively less than the design data. The decrease in the capacity ratio, temperature ranges, pressure drops, and flow rate were negligible but the fouling factor increased by $4.09 \%$.

The results of the $\mathrm{CO}_{2}$ water cooler analysis on the $14^{\text {th }}$ day of the operation are presented in Table 2. It could be seen that the heat transfer coefficient, effectiveness, and the heat duty were $5.53 \%, 6.25 \%$, and $1.78 \%$ respectively less than the design values. The deviation of the calculated data of flow rate, capacity ratio, temperature ranges, pressure drops, and mass flow rates from their respective design values were not appreciable, nevertheless, the fouling factor has increased by $5.92 \%$ against the design value.

The results for the $21^{\text {st }}$ day of operation are presented in Table 3.It was observed that the build-up of deposits on the heat transfer surface has started to affect some performance parameters when compared with results of Tables 1 and 2 . The overall heat transfer coefficient and the calculated heat duty were found to be $8.48 \%$ and $2.72 \%$ less than the actual design values. The difference could be because of the specific heat capacity deviation with temperature or heat loss due to radiation from the hot shell side. The variation in the value of capacity ratio, temperature ranges, flow rate, mass flow rates, LMTD were not practically noticeable. The fouling factor was $9.32 \%$ greater than the design value. The effectiveness of the calculated value was $9.02 \%$ less than the design value.
Table 4 presents the results of $\mathrm{CO}_{2}$ water cooler analysis for $28^{\text {th }}$ day of operation. It was observed that the overall heat transfer coefficient and the effectiveness were $14.62 \%$ and $13.39 \%$ less than the design values. Whereas, the heat duty was $4.75 \%$ less than the design value, Capacity ratio and LMTD were $16.47 \%$ and $15.19 \%$ respectively greater than the design values while temperature ranges (hot and cold), flow rate, and pressure drops were (3.5\% and $7.8 \%), 0.42 \%$, and $10.32 \%$ respectively less than the design value. It was also shown that the fouling factor was increased to $17.11 \%$ against the design value which was as a result of the high accumulation of deposits on transfer area. Table 5 shows a similar trend with Tables 1-4 for the $\mathrm{CO}_{2}$ water cooler for $35^{\text {th }}$ day of operation. From this Table, the results show that the overall heat transfer coefficient and the heat duty were $23.68 \%$ and $8.67 \%$ less than the design values due to the effect of fouling.It should be noted that the company uses river water treated with inhibitors as coolant in cooling the hot $\mathrm{CO}_{2}$.

Table 1 presents the results of $\mathrm{CO}_{2}$ water cooler on the 7 th day of operating the shell and tube heat exchanger. The capacity ratio and LMTD were $23.96 \%$ and $27.54 \%$ respectively greater than the design value. The effectiveness of the heat exchanger has also decreased by $17.52 \%$ of the design value due to high rate of fouling accumulation on heat transfer area which led to reduction of active area of heat transfer. 


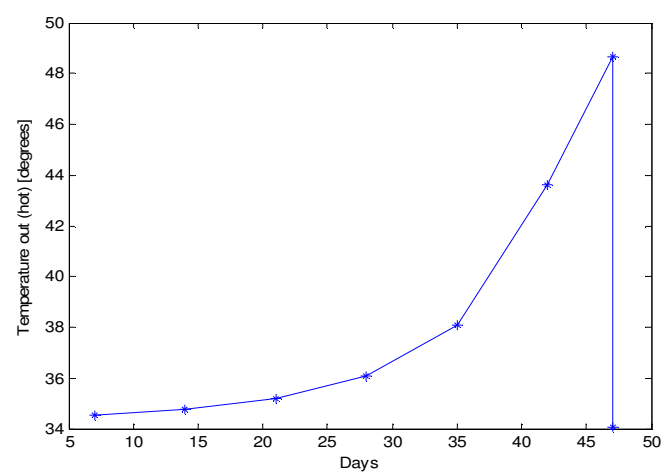

Figure 2: Plot of $\mathrm{CO}_{2}$ outlet temperature against days of operation

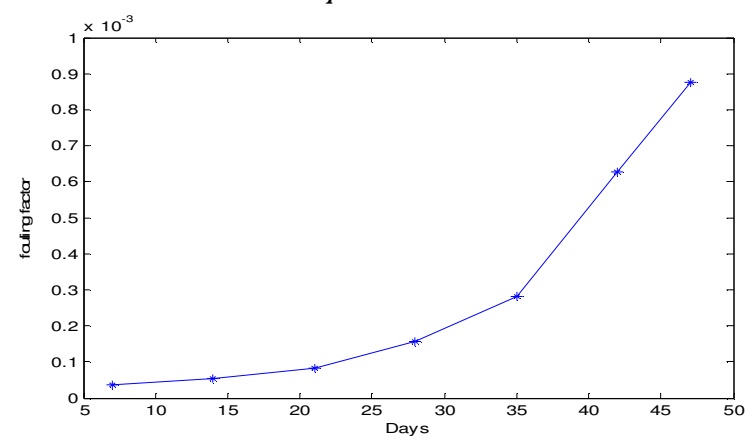

Figure 3: Plot of fouling factor against the number of days

Table 6 shows the results of $\mathrm{CO}_{2}$ water cooler analysis for the $42^{\text {nd }}$ day of operation. The table shows that the accumulated deposits have increased greatly and was affecting the heat exchanger adversely therefore, influencing the performance of the heat exchanger. This is evident in all other parameters calculated.

Table 7 shows the results of $\mathrm{CO}_{2}$ water cooler analysis for the $47^{\text {th }}$ day of operation.

Generally, it was observed that while the values of parameters like overall heat transfer coefficient, the heat duty and effectiveness were decreasing continuously with days of operation compared with the design values, fouling factor, capacity ratio and LMTD values were increasing. This could be seen to be as a result of rapid accumulation of deposits on the heat exchanger surface which can be testified to with the increase in the fouling factor. This fouling effect on the heat exchanger surface affected the performance of the $\mathrm{CO}_{2}$ water cooler.

Figure 2 shows the plot of outlet temperature of $\mathrm{CO}_{2}$ against number of days of operation. From this figure, it was observed that the outlet temperature of $\mathrm{CO}_{2}$ increased appreciably at about 27 th day of operation until the outlet temperature reached the maximum of $48.4^{\circ} \mathrm{C}$ on the $47^{\text {th }}$ day of operation as against an expected outlet temperature of $34^{\circ} \mathrm{C}$, when the unit

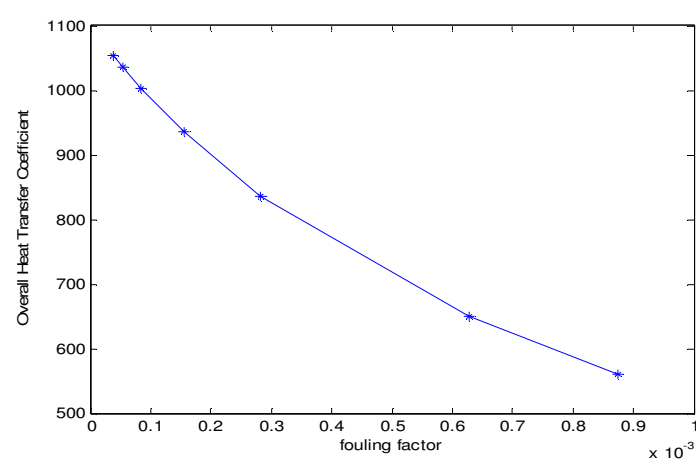

Figure 4: Plot of overall heat transfer coefficient against fouling factor

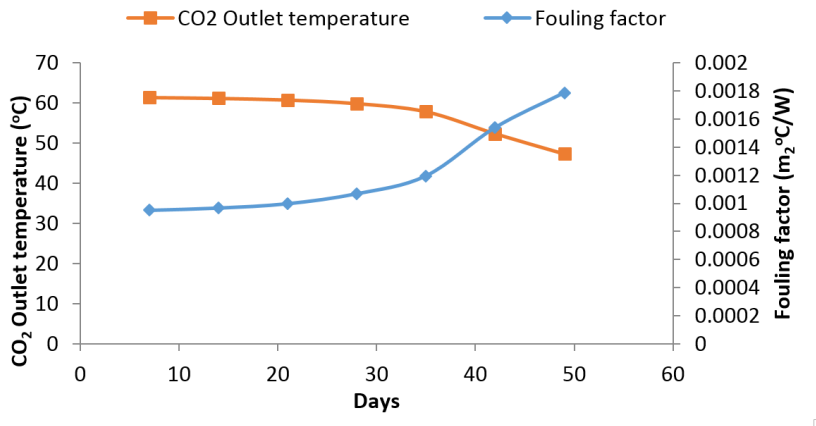

Figure 5: Plot of fouling factor against outlet temperature

was eventually shut down. This implies that effective heat exchange did not take place as a result of fouling. Figure 3 shows the plot of fouling factor against the number of days of operation of $\mathrm{CO}_{2}$ water cooler. From this figure it can be seen that there is a sharp increase in the fouling factor from the $27^{\text {th }}$ day of operation. As it can be observed the fouling factor has affected the heat exchanger adversely. The implication of this rapid increase in the fouling factor was that, the effectiveness and the performance of the heat exchanger decreased rapidly beginning from $27^{\text {th }}$ day of operation due to the reduced surface heat exchange area.

Figure 4 shows the plot of overall heat transfer coefficient against fouling factor. From this figure, it was observed that as the fouling factor was increasing, the overall heat transfer coefficient was decreasing. This is traceable to the difference in the temperature range of the cold fluid and hot fluid which was due to the minimized active area of heat transfer surface as a result of the fouling accumulation.

The results generally agreed with those of Genic et al. [9] and Lebele-Alawa and Okpara [2] that fouling affects the working performance of heat exchangers. Figure 5 presents the plot of fouling factor against $\mathrm{CO}_{2}$ outlet temperature for the maintenance period. As it can be seen, the $\mathrm{CO}_{2}$ Outlet temperature and fouling 
factor sharply deviated around the $30^{\text {th }}$ day of operation. This could be as a result of the increase in the level of dirt in the heat exchanger surface area.

\section{CONCLUSION}

This study has analyzed the effect of fouling on the overall performance of a shell and tube heat exchanger. The heat exchanger considered was a $\mathrm{CO}_{2}$ water cooler that uses treated river water as coolant on the tube side. The results obtained for the $\mathrm{CO}_{2}$ water cooler show that on average, the deviation of the overall heat transfer coefficient, heat duty, and effectiveness were $24.10 \%, 26.27 \%$ and $17.17 \%$ respectively. The results also revealed that fouling factor was $31.58 \%$ more than the design value over a period of 47 days of operation. Fouling adversely affected the performance parameters of the heat exchangers such as: overall heat transfer coefficient, effectiveness, heat duty etc. As a result, the pressure drop and the entire system performance were affected. The study therefore recommended that the periodic maintenance of the $\mathrm{CO}_{2}$ water cooler should be carried out after every 30 days of operation.

\section{Nomenclature}

$A_{s}$ is the Heat Transfer $\operatorname{Area}\left(A_{s}\right), C_{p h}$ is the Specific Heat Capacity of hot Fluid $\left(k J / \mathrm{kg}^{\circ} \mathrm{C}\right), C_{p c}$ is the Specific heat capacity of cold fluid $\left(\mathrm{kJ} / \mathrm{kg}^{\circ} \mathrm{C}\right), R_{f}$ is the Fouling Factor $\left(m^{2}{ }^{\circ} \mathrm{C} / W\right), \dot{\mathrm{m}}_{h}$ is the Mass Flow Rate of hot fluid $(\mathrm{kg} / \mathrm{s})$

$\dot{\mathrm{m}}_{c}$ is the Mass Flow Rate of cold fluid $(\mathrm{kg} / \mathrm{s}), Q_{h}$ is the Heat Duty of hot Fluid $(k W), R$ is the Capacity Ratio, $\varepsilon$ is the Effectiveness, $T_{h, i}$ is the inlet Temperature of hot fluid $\left({ }^{\circ} \mathrm{C}\right), T_{h, o}$ is the Outlet Temperature of hot fluid $\left({ }^{\circ} \mathrm{C}\right), T_{c, i}$ is the Inlet Temperature of cold fluid $\left({ }^{\circ} \mathrm{C}\right), T_{c, o}$ is the Outlet Temperature of cold fluid $\left({ }^{\circ} \mathrm{C}\right), U$ is the Overall heat transfer co-efficient, $U_{c a l}$ is the Overall Heat Transfer Coefficient from Data $\left(W / m^{2}{ }^{\circ} \mathrm{C}\right), U_{\text {clean }}$ is the Overall Heat Transfer Coefficient from Design ( $W / m^{2}{ }^{\circ} \mathrm{C}$, LMTD is Log Mean Temperature Difference $\left({ }^{\circ} \mathrm{C}\right)$

$\Delta T_{l m}=$ LMTD, TEMA is the Tubular exchanger manufacturing association, $C_{\min }$ is the minimum heat capacity rate, $C_{\max }$ is the maximum heat capacity rate, $Q_{\max }$ is the maximum heat transfer and $(k J), Q_{a c t}$ is the actual heat transfer $(k J)$.

\section{REFERENCES}

[1] Cengel, .A., Yunus, (1998). "Heat transfer, a practical approach" Mc-Graw_Hill, $2^{\text {nd }}$ edition.

[2] Lebele-Alawa B. T. and Innocent Okpara Ohia, (2014) "Influence of Fouling on Heat Exchanger Effectiveness in a Polyethylene Plant". Energy and Power 4 (2): 29-34

[3] Hesselgreaves, J. E. (2002). "An Approach to fouling Allowance in the Design of compact Heat Exchangers". Applied Thermal Engineering, 22, 700720.

[4] Mostafa M., Awad, (2011). "Heat Transfer Theoretical Analysis, Experimental Investigations and Industrial Systems" Mansoura University, Faculty of Engineering, Mech. Power Eng. Dept. ,Egypt. ISBN 978-953-307-226-5, 507-508.

[5] Kelvin, M., (2006) "Increasing Heat Exchanger Performance" Procurement of Bryan Research and Engineering incorporated, Bryan, Texas 1-13.

[6] Kukulka, D. J., (2008) "Evaluation of surface coating on Heat Exchangers" A study at the Great Lakes Research Centre of the University of New York College at Buffalo New York 14222 USA

[7] Bell I. H, Groll, E. A, Honig H. and Odrich T (2009) "Experimental analysis of the effects of particulate fouling on heat exchanger heat transfer and air side pressure drop for a hybrid dry cooler". Proceedings of international conference on heat exchanger fouling and cleaning VIII. June 14-19, 2009 Schladming. Austria.

[8] Ishiyama, M. I., Paterson, W.R., Wilson, D.I., (2011) "The effect of fouling on heat transfer, pressure drop, and throughput in refinery preheat trains: optimization of cleaning schedules". Heat Transfer Engineering. 30(10-11): 805-814.

[9] Genic, S. B., Jacimovic, B. M., Mandic, D., Petrovic, D., (2012). "Experimental determination of fouling factor on plate heat exchangers in district heating system". Energy and Building 50:204-211.

[10] Kho, T. (1998) “Effect of Flow Distribution on Scale Formation in Plate and Frame Heat Exchangers" Ph.D. thesis University of Surrey.

[11] Ali Bani Kananeh and Julian Peschel, (2012)."Fouling in Plate Heat Exchangers: Some Practical Experience" GEA PHE Systems Germany 